\title{
Evaluating occupational hazards using information known only to employers: a comparative study
}

\author{
LORRAINE R JOHN, ${ }^{1}$ G M MARSH, ${ }^{2}$ AND P E ENTERLINE ${ }^{2}$ \\ From the Cleft Palate Center, ${ }^{1}$ and the Department of Biostatistics, ${ }^{2}$ Graduate School of Public Health, \\ University of Pittsburgh, Pittsburgh PA 15261, USA
}

ABSTRACT A comparative study was conducted to assess empirically the suspected bias associated with occupational health studies based only on information obtainable from employers' records. Standardised mortality ratios were extracted from five occupational cohorts for which extensive follow up had been conducted and were compared with proportional mortality ratios based on deaths known (KTE) and unknown (UTE) to the employer, and on total deaths. For the five cohorts examined the suspected bias for the cause of death categories all cancer, respiratory cancer, heart disease, and accidents was generally found to be minimal unless the number of UTE deaths was in excess of $75 \%$. Furthermore, a strong inverse relationship was observed between the percentage of UTE deaths and the level of agreement between proportional mortality ratios based on KTE deaths and total deaths. In partial support of these findings it was also observed that workers who left the industry in three of the five cohorts subsequently experienced similar overall mortality compared with those who continued employment. These findings should serve as a rough indication of the potential value of estimating disease risks from KTE deaths and serve as a guide for other investigators using limited data.

Occupational health researchers generally agree that the "best" estimate of risk that can be extracted from an industrial population is the one whose underlying study design contains the most information about the population at risk. With knowledge of the size and demographic composition of the population at risk, standard mortality rates may be used to compute expected numbers of deaths and corresponding summary measures of risk such as the widely used standardised mortality ratio (SMR). This type of study design may not be practical, however, since its cost in terms of time and money could exceed those available to the investigator. In the absence of knowledge of the population at risk, or when funds are low, investigators can conduct a proportional mortality ratio (PMR) analysis by comparing the relative frequency of specific causes of death among a group of decedents with the corresponding frequency in a suitable reference population. The PMR method has generally been regarded as deficient, however, because of the inability of relative measures to provide information about

Received 26 July 1982

Accepted 26 August 1982 absolute rates.' Several authors have conducted theoretical and empirical studies on the use of SMR and PMR for assessing occupational hazards. ${ }^{1-3}$

The most readily available and least expensive decedent group for study under the PMR approach is usually one which can be identified exclusively from union or employers' records. ${ }^{46}$ Several studies of deaths routinely reported to labour unions or readily available from employers' records ${ }^{7-10}$ illustrate this approach. Unfortunately, estimates of risk based on deaths identified from employers' records include only those workers employed at the time of death (actives) and workers who died while receiving a pension (retirees). Generally, the vital status of individuals who left employment for reasons other than retirement is not known to employers.

Comparisons of estimates of risk obtained from various occupational cohort subgroups such as actives, retirees, and terminations have been rather limited. Redmond et al examined the potential bias introduced by ignoring study members who end employment. "I In this study of United States steelworkers almost $45 \%$ of the deaths from malignancies and $21 \%$ of the deaths from heart and circulatory diseases among employees and former em346 
would be missed if analysis were based merely on deaths identified from employers' records.

In another study of the steelworker cohort Collins and Redmond obtained an estimate of risk using only retired members, ${ }^{12}$ noting that this type of study would be relatively inexpensive by comparison with a study containing all workers. The lung cancer hazard previously identified in the steelworker cohort by Lloyd was also detected in this study of retired steelworkers. ${ }^{13}$ In a second paper Collins and Redmond noted that there may be certain diseases, such as lymphatic and haematopoietic tissue cancers, for which retiree studies would not detect an increased risk. ${ }^{14}$

DeCoufle and Thomas conducted a proportionate mortality analysis of three subgroups of the decedent population of an industry, ${ }^{15}$ together with the complete set of decedents in an attempt to determine what differences might exist among estimates of risk based on three groups of the total decedent population-retiree deaths, deaths occurring among active employees, and all other deaths. The authors noted that the conclusions they drew from the analysis about the active deaths were similar to those they drew from the analysis of the complete set of deaths, with the exception of one disease (tuberculosis).

In attempting to explain differential mortality patterns among various cohort subgroups one must consider that unhealthy people either do not enter the labour force or eventually leave employment to seek other occupations or to retire from work altogether. This selection factor has received much attention and is most commonly referred to as having a "healthy worker" effect on employed populations. ${ }^{16-18}$ In two studies conducted by Fox and Collier this healthy worker effect was shown to diminish 15 years after entering an industry. 1920 Their data also suggest that workers who leave employment go on to experience greater overall mortality than those who remain. Moreover, this difference extended to deaths from cancer, circulatory disease, and respiratory disease.

Although these studies tend to indicate that the mortality experience of certain occupational cohort subgroups generally differs, the practical usefulness of risk estimates based on these subgroups has not been fully established. The question of whether a measure of risk, such as the PMR, obtained from a subgroup of the total cohort adequately reflects the mortality of the entire cohort remains unresolved.

The purpose of this article is to provide additional empirical comparisons of the mortality experience of various cohort subgroups relative to that of the total cohort, and to examine further the biases that may be introduced by studying only those em- ployees whose vital status is known from company records. Ideally, information from these and earlier empirical comparisons can be synthesised and used to establish general conditions under which occupational hazards can be reliably identified through relatively quick and cheap study designs.

\section{Materials and methods}

Data from five historical prospective studies at the department of biostatistics of the University of Pittsburgh were used in the comparative analysis. Table 1 describes the five occupational cohorts and the periods during which mortality was examined.

The vital status of each cohort member at the termination of the follow up period was determined by referring to employers' records, the Social Security Administration, state driver's licence files, Veteran's Administration files, personal contacts with relatives, friends, and neighbours, and other miscellaneous follow up sources. Death certificates were requested for all known decedents, and the primary cause of death was coded by an independent nosologist according to the seventh revision of the International Classification of Diseases and Causes of Death (ICD). ${ }^{21}$ For each cohort it was assumed that if a member died while employed (active death) or after retirement (retiree death) the death would be noted on the employee's work history and, hence, would be known to the employer (KTE deaths). Deaths occurring after leaving employment for reasons other than retirement were assumed to be unknown to the employer* (UTE deaths).

Table 2 shows the final results of the follow up efforts for each cohort and its subgroups; the death certificate ascertainment rate exceeded $95 \%$ in each cohort. The high follow up and death certificate ascertainment rates for the five cohorts virtually eliminate the potential biases which can occur in historical prospective mortality studies when such high rates are not achieved. Table 2 also shows that cohorts 1 and 2 are relatively older populations with both having more than one third of all members dead (38.2\% and $35.2 \%$, respectively).

The large percentage of men and deaths within the termination subgroups of cohorts 1,4 , and 5 (table 2) permitted an examination of the bias noted by Redmond et al which may result from an analysis which excludes this subgroup. " Specifically, the

*Companies with investiture policies may have knowledge of the vital status of long term (usually 10 or more years service) employees who left before retirement. The relatively small contribution of this follow up mechanism in the participating plants in this report was not considered. 
Table 1 Cohort defunitions and periods during which mortality was examined

\begin{tabular}{lllll}
\hline Cohort & $\begin{array}{l}\text { Plants } \\
\text { represented }\end{array}$ & $\begin{array}{l}\text { Definition } \\
\text { period }\end{array}$ \\
\hline 1 & Copper smelter workers $(\mathrm{n}=2776)$ & 1 & All men employed at least one year between 1.1 .40 and 31.12 .64 & $1940-76$ \\
2 & Nickel workers $(\mathrm{n}=1855)$ & 1 & All men employed at least one year before 1.1 .48 & $1948-74$ \\
3 & Chemical workers $(\mathrm{n}=2490)$ & 1 & All men employed at least one year between 1.1 .49 and 31.12 .63 & $1949-76$ \\
4 & Fibrous glass workers $(\mathrm{n}=6023)$ & 5 & All men employed at least one year between 1.1 .45 and 31.12.63* & $1945-73$ \\
5 & Mineral wool workers $(\mathrm{n}=1026)$ & 3 & All men employed at least one year between 1.1 .45 and 31.12.63 & $1945-73$ \\
\hline
\end{tabular}

*Contains one plant with minimum six months' entrance criterion.

Table 2 Summary of vital and working status* at end of study period for members of five occupational cohorts. Percentages in parentheses are based on corresponding row total

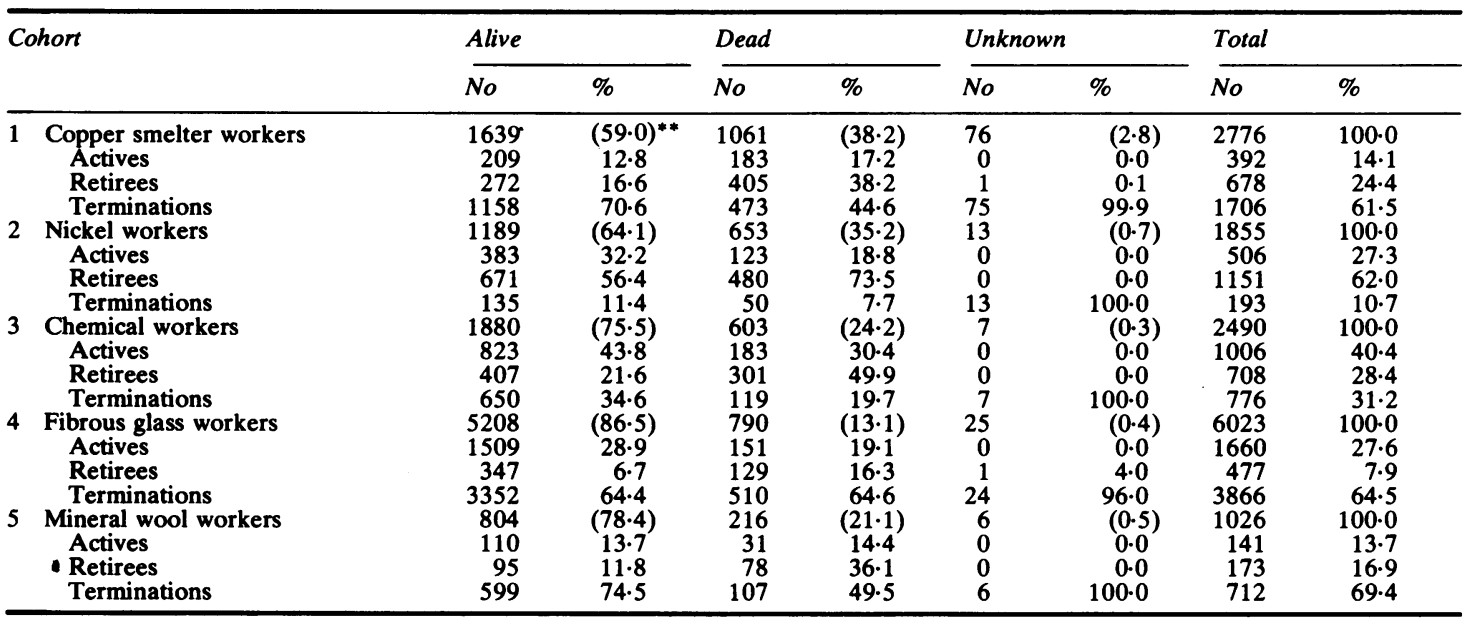

*Active and alive = Employed at end of study period.

Active and dead $=$ Died while employed.

** Percentage in parentheses based on corresponding row total.

effect of excluding this termination subgroup in each cohort was examined by comparing cause-specific PMRs based both on KTE deaths and UTE deaths to the corresponding PMRs based on the total decedent group. In addition, since knowledge of the population at risk was available it was possible to compare the cause specific subgroup PMRs with the corresponding total cohort SMR. This latter comparison was of particular interest since it has been shown that the cause specific PMR provides a good approximation to the relative standardised mortality ratio (RSMR) - that is, the ratio of the cause specific SMR to the SMR for all causes. ${ }^{1}$

In an attempt to determine the effect of continued industrial employment on subsequent mortality, cohort members who survived 15 years after entering the industry were separated according to whether they remained or separated from the industry. The mortality experiences of these two groups of men were examined in each of the five cohorts to compare the present study results with those of Fox and Collier's study which used the same methodology. ${ }^{19}$

All summary indices of risk presented in this paper (SMRs and PMRs) were generated using the occupational cohort mortality analysis programme (OCMAP) developed by Marsh and Preininger which uses the modified life table technique to obtain person-years at risk. ${ }^{22}$ The expected number of deaths for all SMRs and PMRs were calculated using the 1940-75 United States white male five year average annual age specific death rates (seventh revision ICD) contained in OCMAP. The category "all causes" or total deaths was used as the base or denominator for all PMRs calculated. The statistical significance of the SMRs and PMRs were determined using the methods developed by Bailer and Ederer and by Miettinen, respectively. ${ }^{23}{ }^{24}$ 
Table 3 Proportion of deaths unknown to employer from selected causes for fve occupational cohorts

\begin{tabular}{|c|c|c|c|c|c|c|c|c|c|c|}
\hline \multirow[t]{2}{*}{$\begin{array}{l}\text { Cause of death } \\
\text { (ICD } 7 \text { th revision code) }\end{array}$} & \multicolumn{2}{|c|}{$\begin{array}{l}\text { Copper smelter } \\
\text { workers }\end{array}$} & \multicolumn{2}{|l|}{$\begin{array}{l}\text { Nickel } \\
\text { workers }\end{array}$} & \multicolumn{2}{|l|}{$\begin{array}{l}\text { Chemical } \\
\text { workers }\end{array}$} & \multicolumn{2}{|c|}{$\begin{array}{l}\text { Fibrous glass } \\
\text { workers }\end{array}$} & \multicolumn{2}{|c|}{$\begin{array}{l}\text { Mineral wool } \\
\text { workers }\end{array}$} \\
\hline & $\begin{array}{l}\text { Observed } \\
\text { deaths }\end{array}$ & $\begin{array}{l}\text { \% } \\
\text { unknown }\end{array}$ & $\begin{array}{l}\text { Observed } \\
\text { deaths }\end{array}$ & $\begin{array}{l}\text { \% } \\
\text { unknown }\end{array}$ & $\begin{array}{l}\text { Observed } \\
\text { deaths }\end{array}$ & $\begin{array}{l}\text { \% } \\
\text { unknown }\end{array}$ & $\begin{array}{l}\text { Observed } \\
\text { deaths }\end{array}$ & $\begin{array}{l}\% \\
\text { unknown }\end{array}$ & $\begin{array}{l}\text { Observed } \\
\text { deaths }\end{array}$ & $\begin{array}{l}\text { \% } \\
\text { unknown }\end{array}$ \\
\hline \multirow{5}{*}{$\begin{array}{l}\text { All cancers }(140-205) \\
\text { Digestive system } \\
\text { cancers }(150-159) \\
\text { Respiratory system } \\
\text { cancers (160-164) } \\
\text { Lymphopoietic tissue } \\
\text { cancers }(200-205) \\
\text { All heart disease } \\
\text { (400-443) } \\
\text { Accidents (800-962) }\end{array}$} & 232 & $44 \cdot 4$ & 129 & $5 \cdot 4$ & 127 & $22 \cdot 0$ & 136 & 69.9 & 39 & $48 \cdot 7$ \\
\hline & 66 & 39.4 & 38 & $5 \cdot 3$ & 44 & $16 \cdot 0$ & 66 & 39.4 & 14 & $42 \cdot 9$ \\
\hline & 104 & $43 \cdot 3$ & 39 & $2 \cdot 6$ & 29 & $31 \cdot 0$ & 40 & $82 \cdot 5$ & 14 & $50 \cdot 0$ \\
\hline & 17 & $64 \cdot 7$ & 12 & 0.0 & 11 & $36 \cdot 4$ & 18 & $61 \cdot 1$ & 4 & $50 \cdot 0$ \\
\hline & $\begin{array}{r}414 \\
61\end{array}$ & $\begin{array}{l}37 \cdot 2 \\
64 \cdot 0\end{array}$ & $\begin{array}{r}298 \\
27\end{array}$ & $\begin{array}{r}6 \cdot 8 \\
22 \cdot 2\end{array}$ & $\begin{array}{r}263 \\
29\end{array}$ & $\begin{array}{l}15 \cdot 6 \\
27 \cdot 6\end{array}$ & $\begin{array}{r}366 \\
54\end{array}$ & $\begin{array}{l}58 \cdot 7 \\
70 \cdot 4\end{array}$ & $\begin{array}{l}92 \\
14\end{array}$ & $\begin{array}{l}45 \cdot 7 \\
78 \cdot 6\end{array}$ \\
\hline All causes & 1061 & $44 \cdot 6$ & 653 & 7.7 & 603 & 19.7 & 790 & $64 \cdot 6$ & 216 & 49.5 \\
\hline
\end{tabular}

\section{Results}

Table 3 shows the differences between the five study cohorts with respect to the total number of UTE deaths. The proportion of total UTE deaths is smallest for nickel workers $(7 \cdot 7 \%)$ and largest for fibrous glass workers $(64.6 \%)$. Table 3 also shows that the percentages of UTE deaths vary by cause of death for all five study cohorts. For each cohort, accidental deaths were unknown to the employer more often than deaths from heart disease and cancers. Within the category "all cancers" the percentage of UTE deaths ranged from a minimum of zero for lymphopoietic tissue cancer in nickel workers to a maximum of $82.5 \%$ for respiratory cancer in fibrous glass workers.

Tables 4-7 show the mortality experiences of the various subgroups within each of the five cohorts for four selected causes of death. Based on SMRs computed from the total cohort, two statistically significant excess mortality risks were found among the copper smelter workers for all cancers $(\mathrm{SMR}=124.5)$ and for respiratory cancer $($ SMR $=190.5)$ as shown in tables 4 and 5, respectively. This statistically significant excess mortality risk for all cancers is identified by all the risk estimates shown in table 4, with the exception of the PMR for termination deaths which did, however, suggest excess mortality (PMR $=115 \cdot 3)$. The lack of statistical significance is partly due to the smaller number of deaths observed in this cohort subgroup. The statistically significant excess mortality from respiratory cancer, based on the total cohort SMR, is maintained, however, by each of the three PMR estimates (table 5).

Generally, the PMRs for KTE deaths are similar in magnitude and direction (greater than or less than 100) to the PMRs for all deaths over the four cause of death categories for all five study cohorts (tables 4-7). As might be expected, agreement between these two risk estimates is improved as the percentage of UTE deaths decreases, as in the case of the nickel alloy workers who have the lowest percentage of UTE deaths $(7.7 \%)$ of the five cohorts studied. Indeed, as the number of UTE deaths increases, the absolute and relative magnitude of the differences between these two risk estimates does increase for each of the four selected causes of death.*

Furthermore, in only three cases did the relative absolute difference between the total PMR and PMR based on KTE deaths exceed $15 \%$. In two of these the percentage of UTE deaths exceeded $75 \%$ (respiratory cancer in cohort 4 glass workers, UTE deaths $=82.5 \%$ and accidents in cohort 5, UTE deaths $=78.6 \%$ ). The $16.5 \%$ relative difference in PMRs noted for respiratory cancer in cohort 1 was based on $43.3 \%$ UTE deaths, however. This difference was atypical of all other such differences found when the percentage of UTE deaths was of this magnitude. These empirical findings suggest that unless the percentage of UTE deaths is large (in excess of $75 \%$ ) a PMR analysis of KTE deaths will generally produce risk estimates similar to those of a PMR analysis based on total deaths.

Due to the empirical relationship that exists between the PMR and the SMR (cause specific $P M R \cong$ cause specific SMR/all causes SMR), close agreement between these two risk estimates can be expected when the all causes SMR, based on total cohort is close to $100 .{ }^{12}$ In this study predicting how well the PMRs based on all deaths agreed with the total cohort SMRs was possible since, for all cohorts,

*Spearman rank order correlation coefficients ${ }^{25}$ computed between the percentage of deaths unknown to employer and the absolute difference between the two risk estimates were $0.87,0.87,0.68$, and 0.92 for all cancers, respiratory cancer, heart disease, and accidents, respectively. 
Table 4 Observed numbers of deaths and PMRs and SMRs obtained from various cohort subgroups within five occupational cohorts. Cause of death: all cancers

\begin{tabular}{|c|c|c|c|c|c|}
\hline \multicolumn{2}{|c|}{ Cohort } & \multicolumn{3}{|c|}{$\begin{array}{l}\text { PMRs } \\
\text { (observed deaths) }\end{array}$} & \multirow{2}{*}{$\begin{array}{l}\text { SMRs } \\
\text { (observed deaths) } \\
\text { Total } \\
\text { cohort }\end{array}$} \\
\hline & & $\begin{array}{l}\text { Known to } \\
\text { employer }\end{array}$ & $\begin{array}{l}\text { Unknown to } \\
\text { employer }\end{array}$ & Total & \\
\hline 2 & $\begin{array}{l}\text { Copper smelter workers } \\
\text { Nickel workers } \\
\text { Chemical workers } \\
\text { Fibrous glass workers } \\
\text { Mineral wool workers }\end{array}$ & $\begin{array}{l}124 \cdot 4^{* *} \\
(129) \\
109 \cdot 6 \\
(122) \\
107 \cdot 0 \\
(99) \\
78 \cdot 3 \\
(41) \\
102 \cdot 9 \\
(20)\end{array}$ & $\begin{array}{l}115 \cdot 3 \\
(103) \\
74 \cdot 5 \\
(7) \\
121 \cdot 9 \\
(28) \\
100 \cdot 7 \\
(95) \\
96 \cdot 8 \\
(19)\end{array}$ & $\begin{array}{l}120 \cdot 2^{* *} \\
(232) \\
106 \cdot 8 \\
(129) \\
109 \cdot 9 \\
(127) \\
92 \cdot 6 \\
(136) \\
99.9 \\
(39)\end{array}$ & $\begin{array}{l}124 \cdot 5^{* *} \\
(232) \\
89 \cdot 5 \\
(129) \\
107 \cdot 4 \\
(127) \\
88 \cdot 1 \\
(136) \\
95 \cdot 4 \\
(39)\end{array}$ \\
\hline
\end{tabular}

* Statistically significant at $1 \%$ level.

Table 5 Observed numbers of deaths and PMRs and SMRs obtained from various cohort subgroups within fue occupational cohorts. Cause of death: respiratory cancer

\begin{tabular}{|c|c|c|c|c|c|}
\hline \multicolumn{2}{|c|}{ Cohort } & \multicolumn{3}{|c|}{$\begin{array}{l}\text { PMRs } \\
\text { (observed deaths) }\end{array}$} & \multirow{2}{*}{$\begin{array}{l}\text { SMRs } \\
\text { (observed deaths) } \\
\begin{array}{l}\text { Total } \\
\text { cohort }\end{array}\end{array}$} \\
\hline & & $\begin{array}{l}\text { Known to } \\
\text { employer }\end{array}$ & $\begin{array}{l}\text { Unknown to } \\
\text { employer }\end{array}$ & Total & \\
\hline $\begin{array}{l}1 \\
2 \\
3 \\
4 \\
5\end{array}$ & $\begin{array}{l}\text { Copper smelter workers } \\
\text { Nickel workers } \\
\text { Chemical workers } \\
\text { Fibrous glass workers } \\
\text { Mineral wool workers }\end{array}$ & $\begin{array}{l}211.4^{* *} \\
(59) \\
115.0 \\
(38) \\
68.8 \\
(20) \\
41 \cdot 7^{*} \\
(7) \\
127.2 \\
(7)\end{array}$ & $\begin{array}{l}152.9 * * \\
(45) \\
32.7 \\
(1) \\
111.6 \\
(9) \\
107.2 \\
(33) \\
109.8 \\
(7)\end{array}$ & $\begin{array}{l}181.4 * * \\
(104) \\
108.0 \\
(39) \\
78.1 \\
(29) \\
84.1 \\
(40) \\
117.9 \\
(14)\end{array}$ & $\begin{array}{l}190.5^{* *} \\
(104) \\
89.4 \\
(39) \\
77.8 \\
(29) \\
81.9 \\
(40) \\
115.4 \\
(14)\end{array}$ \\
\hline
\end{tabular}

* Statistically significant at $5 \%$ level.

* Statistically significant at $1 \%$ level.

Table 6 Observed numbers of deaths and PMRs and SMRs obtained from various cohort subgroups within five occupational cohorts. Cause of death: all heart disease

\begin{tabular}{|c|c|c|c|c|c|}
\hline \multicolumn{2}{|c|}{ Cohort } & \multicolumn{3}{|c|}{$\begin{array}{l}\text { PMRs } \\
\text { (observed deaths) }\end{array}$} & \multirow{2}{*}{$\begin{array}{l}\text { SMRs } \\
\text { (observed deaths) } \\
\text { Total } \\
\text { cohort }\end{array}$} \\
\hline & & $\begin{array}{l}\text { Known to } \\
\text { employer }\end{array}$ & $\begin{array}{l}\text { Unknown to } \\
\text { employer }\end{array}$ & Total & \\
\hline $\begin{array}{l}1 \\
2 \\
3\end{array}$ & $\begin{array}{l}\text { Copper smelter workers } \\
\text { Nickel workers } \\
\text { Chemical workers } \\
\text { Fibrous glass workers } \\
\text { Mineral wool workers }\end{array}$ & $\begin{array}{l}98.9 \\
(260) \\
102.7 \\
(280) \\
104.9 \\
(222) \\
129.3 * * \\
(151) \\
103.2 \\
(50)\end{array}$ & $\begin{array}{c}79.1 * * \\
(154) \\
84.8 \\
(18) \\
85.7 \\
(41) \\
104.6 \\
(216) \\
93.9 \\
(42)\end{array}$ & $\begin{array}{l}90.5^{* *} \\
(414) \\
101.4 \\
(298) \\
101.4 \\
(263) \\
113.8 * * \\
(367) \\
98.8 \\
(92)\end{array}$ & $\begin{array}{c}93.0 \\
(414) \\
85.6 * * \\
(298) \\
108.0 \\
(263) \\
107.9 \\
(367) \\
95.0 \\
(92)\end{array}$ \\
\hline
\end{tabular}

**Statistically significant at $1 \%$ level. 
Table 7 Observed numbers of deaths and PMRs and SMRs obtained from various cohort subgroups within fve occupational cohorts. Cause of deaths: accidents

\begin{tabular}{|c|c|c|c|c|c|}
\hline \multicolumn{2}{|c|}{ Cohort } & \multicolumn{3}{|c|}{$\begin{array}{l}\text { PMRs } \\
\text { (observed deaths) }\end{array}$} & \multirow{2}{*}{$\begin{array}{l}\text { SMRs } \\
\text { (observed deaths) } \\
\text { Total } \\
\text { cohort }\end{array}$} \\
\hline & & $\begin{array}{l}\text { Known to } \\
\text { employer }\end{array}$ & $\begin{array}{l}\text { Unknown to } \\
\text { employer }\end{array}$ & Total & \\
\hline 1 & $\begin{array}{l}\text { Copper smelter workers } \\
\text { Nickel workers } \\
\text { Chemical workers } \\
\text { Fibrous glass workers } \\
\text { Mineral wool workers }\end{array}$ & $\begin{array}{c}81 \cdot 5 \\
(22) \\
83.9 \\
(21) \\
80.0 \\
(21) \\
73.3 \\
(16) \\
56.7 \\
(3)\end{array}$ & $\begin{array}{l}104.6 \\
(39) \\
169.4 \\
(6) \\
75.6 \\
(8) \\
79.2 \\
(38) \\
127.4 \\
(11)\end{array}$ & $\begin{array}{c}94.6 \\
(61) \\
94.5 \\
(27) \\
79.4 \\
(29) \\
77.6 * \\
(54) \\
100.6 \\
(14)\end{array}$ & $\begin{array}{c}102 \cdot 2 \\
(61) \\
72 \cdot 0 \\
(27) \\
68 \cdot 7^{*} \\
(29) \\
62 \cdot 8^{* *} \\
(54) \\
66 \cdot 3 \\
(14)\end{array}$ \\
\hline
\end{tabular}

* Statistically significant at $5 \%$ level.

* -Statistically significant at $1 \%$ level.

the all causes SMRs based on the total cohort were known and are as follows: cohort 1, 103.5; cohort 2 , 83.8 (p < 0.01); cohort 3, 95.8; cohort 4, 92.6 $(p<0.05)$; and cohort $5,94.5$. The values suggest that these two risk estimates should be similar for all cohorts with the possible exception of cohort 2. Examination of tables 4-7 shows that the PMRs based on all deaths are, in fact, consistently greater in magnitude and direction than the total cohort SMRs for cohort 2.

Table 8 shows the mortality experiences of two groups of men, those who left the industry and those who continued employment for each cohort. The "current" group of workers was composed of indi- viduals alive 15 years after entering the industry who had accrued 15 or more years of employment. The "past" group of workers was composed of individuals alive 15 years after entering the industry who had accrued less than 15 years of employment. Since the classification of each individual as being either a "current" or "past" worker was dependent on years of employment and not employment status, both groups may contain retired, terminated, or actively employed individuals as well as workers who died while employed.

Table 8 shows that past workers experienced similar overall mortality when compared with current workers for three of the five study cohorts (copper

Table 8 Comparison of observed numbers of deaths (in parentheses) and SMRs from major causes of death for current and for past workers alive 15 years after entry into industry

\begin{tabular}{|c|c|c|c|c|c|c|c|c|c|c|}
\hline \multirow[t]{2}{*}{$\begin{array}{l}\text { Cause of death } \\
\text { (ICD code) }\end{array}$} & \multicolumn{2}{|c|}{$\begin{array}{l}\text { Copper smelter } \\
\text { workers }\end{array}$} & \multicolumn{2}{|l|}{$\begin{array}{l}\text { Nickel } \\
\text { workers }\end{array}$} & \multicolumn{2}{|c|}{$\begin{array}{l}\text { Chemical } \\
\text { workers }\end{array}$} & \multicolumn{2}{|c|}{$\begin{array}{l}\text { Fibrous glass } \\
\text { workers }\end{array}$} & \multicolumn{2}{|c|}{$\begin{array}{l}\text { Mineral wool } \\
\text { workers }\end{array}$} \\
\hline & Current & Past & Current & Past & Current & Past & Current & Past & Current & Past \\
\hline All cancers (140-205) & $\begin{array}{l}130.7^{* * *} \\
(134)\end{array}$ & $\begin{array}{l}126 \cdot 7^{*} \\
(80)\end{array}$ & $\begin{array}{r}95.9 \\
(122)\end{array}$ & ${ }^{38 \cdot 4^{*}}$ & $\begin{array}{l}103 \cdot 4 \\
(86)\end{array}$ & $\begin{array}{l}119 \cdot 3 \\
(18)\end{array}$ & $\begin{array}{l}86-9 \\
(36)\end{array}$ & $\begin{array}{l}93.8 \\
(44)\end{array}$ & $\begin{array}{l}103 \cdot 8 \\
(21)\end{array}$ & $\begin{array}{l}69 \cdot 0 \\
(8)\end{array}$ \\
\hline $\begin{array}{l}\text { Digestive system } \\
\text { cancers (150-159) }\end{array}$ & $\begin{array}{l}123.0 \\
(43)\end{array}$ & $\begin{array}{l}116 \cdot 8 \\
(21)\end{array}$ & $\begin{array}{l}87 \cdot 3 \\
(35)\end{array}$ & $\begin{array}{l}57 \cdot 9 \\
(2)\end{array}$ & $\begin{array}{l}137 \cdot 7 \\
(34)\end{array}$ & $\begin{array}{l}115 \cdot 0 \\
(5)\end{array}$ & $\begin{array}{l}115 \cdot 2 \\
(13)\end{array}$ & $\begin{array}{l}84 \cdot 1 \\
(11)\end{array}$ & $\begin{array}{l}109 \cdot 2 \\
(7)\end{array}$ & $\begin{array}{l}117 \cdot 6 \\
(4)\end{array}$ \\
\hline ahonginting & $\begin{array}{l}225 \cdot 4^{* *} \\
(63)\end{array}$ & $\begin{array}{l}156 \cdot 8^{*} \\
(34)\end{array}$ & $\begin{array}{l}96 \cdot 5 \\
(38)\end{array}$ & $\begin{array}{l}35 \cdot 7 \\
(1)\end{array}$ & $\begin{array}{l}73.5 \\
(20)\end{array}$ & $\begin{array}{l}84.9 \\
(4)\end{array}$ & $\begin{array}{l}73.4 \\
(11)\end{array}$ & $\begin{array}{l}114 \cdot 2 \\
(18)\end{array}$ & $\begin{array}{l}128 \cdot 5 \\
(8)\end{array}$ & ${ }_{(2)}^{55 \cdot 6}$ \\
\hline $\begin{array}{l}\text { Lymphopoietic tissue } \\
\text { cancers (200-205) }\end{array}$ & $\begin{array}{l}44 \cdot 6 \\
(4)\end{array}$ & $\begin{array}{l}133 \cdot 0 \\
(8)\end{array}$ & $\begin{array}{l}103 \cdot 9 \\
(12)\end{array}$ & $\overline{(0)}$ & ${ }_{(4)}^{51 \cdot 8}$ & $\begin{array}{l}204 \cdot 6 \\
(3)\end{array}$ & $\begin{array}{l}74 \cdot 1 \\
(3)\end{array}$ & $\begin{array}{l}64 \cdot 3 \\
(3)\end{array}$ & $\begin{array}{l}161 \cdot 9 \\
(3)\end{array}$ & $\begin{array}{l}87 \cdot 4 \\
(1)\end{array}$ \\
\hline $\begin{array}{l}\text { All heart disease } \\
(400-443) \\
\text { Accidents (800-962) }\end{array}$ & $\begin{array}{c}98.0 \\
(253) \\
82.9 \\
(18)\end{array}$ & $\begin{array}{c}93.3 \\
(129) \\
91 \cdot 1 \\
(15)\end{array}$ & $\begin{array}{l}83.9 * * \\
(255) \\
69.9 \\
(20)\end{array}$ & $\begin{array}{l}117.4 \\
(33) \\
118 \cdot 7 \\
(3)\end{array}$ & $\begin{array}{l}102 \cdot 6 \\
(193) \\
72 \cdot 6 \\
(14)\end{array}$ & $\begin{array}{l}111 \cdot 2 \\
(39) \\
123 \cdot 5 \\
(5)\end{array}$ & $\begin{array}{l}106 \cdot 1 \\
(92) \\
49.3 \\
(6)\end{array}$ & $\begin{array}{l}128 \cdot 5^{* *} \\
(134) \\
61 \cdot 1 \\
(6)\end{array}$ & $\begin{array}{l}98.6 \\
(47) \\
64.6 \\
(3)\end{array}$ & $\begin{array}{l}96 \cdot 3 \\
(27) \\
104 \cdot 1 \\
(4)\end{array}$ \\
\hline All causes & $\begin{array}{l}102 \cdot 4 \\
(582)\end{array}$ & $\begin{array}{l}110.7 \\
(351)\end{array}$ & $\begin{array}{l}84 \cdot 7^{* *} \\
(570)\end{array}$ & $\begin{array}{l}96 \cdot 8 \\
(60)\end{array}$ & $\begin{array}{r}97 \cdot 3 \\
(413)\end{array}$ & $\begin{array}{l}115 \cdot 3 \\
(94)\end{array}$ & $\begin{array}{r}86-8 \\
(176)\end{array}$ & $\begin{array}{l}115 \cdot 2^{*} \\
(284)\end{array}$ & $\begin{array}{r}95 \cdot 4 \\
(101)\end{array}$ & $\begin{array}{l}95 \cdot 4 \\
(62)\end{array}$ \\
\hline
\end{tabular}

*Statistically significant at $5 \%$ level.

**Statistically significant at $1 \%$ level. 
smelter, nickel, and mineral wool workers), a result not entirely consistent with those of Fox and Collier. ${ }^{1920}$ The raised overall mortality observed for past chemical and fibrous glass workers appears to be largely due to increased heart disease and accident mortality. In fact, the SMRs for accidental deaths were uniformly greater among past em: ployees while the opposite pattern was generally true for deaths from cancer.

\section{Discussion}

Historically, proportional mortality studies based only on KTE deaths have been interpreted with caution because of the suspected bias associated with the failure to include UTE deaths. The empirical results presented here tend to weaken this suspicion since this bias was generally found to be minimal unless the number of UTE deaths was greater than $75 \%$. Furthermore, a strong inverse relationship was consistently observed for four selected causes of death between the percentage of UTE deaths and the level of agreement between PMRs based on KTE deaths and total deaths. These results were somewhat supported by the observation that past workers experienced similar overall mortality when compared with current workers in three of the five cohorts examined.

Although these results were derived from five independent occupational cohorts in a total of 11 plants, they may not represent the general experience. Differential termination and retirement patterns and leave of absence policies could affect the nature of KTE deaths. Thus these findings should be viewed as a rough indication of the potential value of estimating disease risks from KTE deaths and serve as a guide for other investigations using limited data. Further studies need to be conducted to establish the use of risk estimates based on occupational subgroups as a reliable and valid method for evaluating occupational hazards.

\section{References}

\footnotetext{
' Kupper LL, McMichael AJ, Symons MJ, Most BM. On the use of proportional mortality analysis. J Chron Dis 1978;31:15-22.

${ }^{2}$ DeCoufle P, Thomas TL, Pickle LW. Comparison of the propor-
}

tionate mortality ratio and standardized mortality ratios risk measures. Am J Epidemiol 1980;111:263-9.

${ }^{3}$ Redmond CK, Breslin PP. Comparison of methods for assessing occupational hazards. JOM 1975;17:313-7.

4 DeCoufle P, Lloyd JW, Salvin LG. Causes of death among construction machinery operators. JOM 1977;19:123-8.

${ }^{5}$ Lloyd JW, DeCoufle P, Salvin LG. Unusual mortality experience of printing pressmen. JOM 1977;19:543-50.

- DeCoufle P, Lloyd JW, Salvin LG. Mortality by cause among stationary engineers and stationary firemen. JOM 1977;19:679-81.

${ }^{7}$ Pinto SS, Bennett BM. Effect of arsenic trioxide exposure on mortality. Arch Environ Health 1963;7:583-91.

8 Rencher AC, Carter MW, McKee DW. A retrospective epidemiologic study of mortality in a large western copper smelter. JOM 1977;19:754-8.

- Chiazze L, Nichols WE, Wong $O$. Mortality among employees of PVC fabricators. JOM 1977;19:623-8.

${ }^{10}$ Monson RR, Nakano KK. Mortality among rubber workers. II. Other employees. Am J Epidemiol 1976;103:297-303.

" Redmond CK, Smith EM, Lloyd JW, Rush HW. Long-term mortality study of steelworkers: III. Follow-up. JOM 1960;11:513-21.

${ }^{12}$ Collins JF, Redmond CK. The use of retirees to evaluate occupational hazards. I. JOM 1976;18:595-602.

${ }^{13}$ Lloyd JW. Long-term mortality study of steelworkers: V. Respiratory cancer in coke plant workers. JOM 1971;13:5368.

14 Collins JF, Redmond CK. The use of retirees to evaluate occupational hazards. II. JOM 1978;20:260-6.

is DeCoufle P, Thomas TL. A methodological investigation of fatal disease risks in a large industrial cohort. JOM 1979;21:10710.

${ }^{16}$ McMichael AJ. Standardized mortality ratios and the "healthy workers effect." Scratching beneath the surface. JOM 1976;18:165-8.

17 Enterline PE. What do we expect from an occupational cohort? JOM 1975;17:127-8.

18 Gaffey WR. A critique of the standardized mortality ratio. JOM 1976;18:157-60.

${ }^{19}$ Fox AJ, Collier PE. Low mortality rates in industrial cohort studies due to selection for work and survival in the industry. $J$ Prev Soc Med 1976;20:225-30.

${ }^{20}$ Fox AJ, Collier PE. Mortality experience of workers exposed to vinyl chloride monomer in the manufacture of polyvinyl chloride in Great Britain. Br J Ind Med 1977;34:1-10.

${ }^{21}$ National Center for Health Statistics. Seventh revision international classification of diseases adapted for use in the United States. Vol 1 tabular list, vol 2, alphabetical index. Washington: Department of Health, Education, and Welfare. US Government Printing Office, 1957.

${ }^{22}$ Marsh GM, Preininger M. OCMAP: a user oriented occupational cohort mortality analysis program. American Statistician 1980;34:245-6.

${ }^{23}$ Bailer JC, Ederer F. Significance factors for the ratio of a Poisson variable to its expectation. Biometrics 1964;20:639-43.

${ }^{24}$ Miettinen OS. Estimability and estimation in case-referent studies. Am J Epidemiol 1976;103:226-35.

${ }^{25}$ Hollander M, Wolfe D. Nonparametric statistical methods. New York: John Wiley \& Sons, 1973. 